\title{
Metacognitive Strategy Instruction as a Means to Improve Listening Self- Efficacy among Iranian Undergraduate Learners of English
}

\section{Maryam Rahimirad}

Department of Foreign Languages, University of Kashan, Iran, maryamrahimirad@gmail.com

\author{
Abbas Zare-ee \\ Asst. Prof., Department of Foreign Languages, University of Kashan, Iran, \\ zare-ee72@kashanu.ac.ir
}

\begin{abstract}
Metacognitive strategy instruction (MetSI) has been shown to have a strong impact on various aspects of English as a second/foreign language instruction. The present study aimed to investigate the effect of MetSI on the improvement of listening selfefficacy among English-as-a-foreign-language (EFL) learners. A group of sixty female undergraduate learners of English literature at a state-run university in Iran consented to take part in this study. After homogenizing the participants' English proficiency level using a sample section of the British Council IELTS test, 40 learners were selected whose English proficiency fell within intermediate to upperintermediate level. A listening self-efficacy questionnaire (borrowed from Rahimi and Abedini, 2009) was used to measure the participants' level of listening selfefficacy in the pre and post-test phases of the study. The participants were randomly assigned to treatment $(n=20)$ and control $(n=20)$ groups. The treatment group received 8 hours of MetSI during eight sessions based on the model proposed by Vandergrift (2003) while the control group didn't receive any explicit MetSI. The control group received the usual training in listening instead.
\end{abstract}

Keywords: Metacognitive strategy instruction (MetSI), listening self-efficacy, listening comprehension, language instruction, foreign-language

\section{INTRODUCTION}

Unlike their predecessors, listening researchers of the past few decades do not recognize listening as a passive activity any more. They have come to the consensus that effective listening needs to be fostered and improved explicitly (Mendelsohn, 1994). Although teachers are increasingly encouraged to implement listening activities in their classes there's still confusion about effective classroom teaching of this skill. The development of cognitive psychology has paved the way for emerging new approaches to teach listening (Goh, 2008; Lynch, 1998; Macaro, Graham \& Vanderplank, 2007; Rubin, 1994). During recent years some scholars have focused on the impact of strategy 
instruction in this process and have made considerable contributions to this area of research (Vandergrift \& Tafaghodtari, 2010).

The important role of self-efficacy (a person's beliefs of his abilities and accomplishments) in language learning provides essential incentive to explore strategies in listening classes which raise listeners' engagement and self-efficacy. In order to detect the reason of outperformance among some listeners with almost equal intelligence and capabilities, some researchers have concentrated on learning strategies (Cohen, 1998; O'Malley \& Chamot, 1990; Oxford, 1990). Listeners by engaging in stages of MetSI can gain vicarious experience which is observing others performing tasks (Pajares, 1997, 2002). It can stimulate pre-assumption of success in them to pursue their efforts in listening tasks. Since MetSI in listening familiarizes and provides students with five factors of metacognitive knowledge (planning and evaluation, problem solving, directed attention, mental translation and person knowledge) it is hypothesized that it can develop self-regulated learning and provide a context for interpretation. The current research article intends to investigate the impact of MetSI on EFL students' listening self-efficacy.

\section{Review of the Related Literature}

\section{Metacognitive Listening Strategy Instruction}

Although the concept of listening comprehension was once erroneously recognized by many researches, educators and learners as hearing, now in the light of recent developments in applied linguistics and the growing trend of process-oriented approaches to listening, the fallacy of this misconception is increasingly acknowledged. As a matter of fact, while both hearing and listening involve sound perception, listening involves a degree of conscious intention. On the contrary, hearing is "non-selective and involuntary" (Bone, 1994, p.20). Thereby, the scope of what we mean by listening has transcended from the mere task of hearing a text and answering comprehension questions to coordinating various processes and activating different types of knowledge including schemata knowledge to construct meaning.

Modern pedagogy perceives listening as a combination of linguistic (lexical, syntactic, semantic, discursive, phonological) and non-linguistic (schemata, topic, contextual) knowledge (Roberts \& Gous, (2014).

There are three types of learning strategies which have also been applied in listening instruction: 1) cognitive strategies 2) metacognitive strategies, and 3) socio-affective strategies (Chamot, 1993). Cognitive strategies include inference, resourcing and note taking which are unconscious interactions with the material to be learned. Metacognitive strategies involve conscious management and regulation over the learning process. They include planning, concentrating and monitoring. Socio-affective strategies are designed for interacting with peers or management of affection. They include asking questions, collaborating with classmates and controlling stress (O'Malley et al., 1989; Oxford et al., 1989; Vandergrift, 1997). Metacognitive strategy instruction has been one of the most popular research areas within the area of listening strategy instruction as it familiarizes students with five factors of metacognitive knowledge including planning, 
evaluation, problem solving, directed attention, mental translation and person knowledge. These factors can develop self-regulated learning and provide a context for interpretation.

Although the literature base in listening strategy instruction hasn't received enough attention, it is recently focused by listening experts such as Goh (1997, 1998, 2000, 2002), Hasan (2000), Mareschal (2007) and Vandergrift (1997, 2003, 2004) in the past few decades. Initially, most of the listening strategy studies have been investigating patterns and strategies used by successful versus less successful learners. Gradually the line of research shifted to focus on effective strategies and process-oriented approaches to teach listening skill in order to guide the students "learn to listen" so that they can better "listen to learn" (Vandergrift, 2004). Therefore, listening instructors have the responsibility to teach their students to take advantage of strategies rather than merely provide them with oral passages and test them (Mendelsohn, 1995).

Recently, researchers like Vandergrift and Goh (2012) and some other scholars have focused more closely on a metacognitive framework for listening instruction. Here some of the most notable studies are briefly mentioned. Goh (1997) investigated the metacognitive knowledge about listening on a group of Chinese tertiary level students in Singapore. Content analyses of the data registered in listening diaries revealed that person knowledge, task knowledge and strategy knowledge were 3 main categories about ESL listening possessed by students. It was also confirmed that high-skilled listeners showed almost twice metacognitive knowledge about listening compared to low-skilled listeners. Goh (1998) studied Chinese students' listening strategies again in another investigation. She found a series of comprehension strategies through the data collected from group interviews, diaries and individual verbalizations. Six frequently used strategies applied by students were reported to be inference, fixation, contextualization, comprehension, monitoring, directed attention, and selective attention. She also discovered that high-skilled listeners implemented more various strategies compared to less-skilled listeners. The results also revealed that the prior knowledge which learners bring into the task plays a critical role in their comprehension. It was also found that first and second language comprehension have similar underlying strategies. However, when Goh compared listeners' strategy knowledge and strategy use, it was revealed that although listeners identified some listening strategies as useful, few students made use of them in practice probably because listeners use some strategies "spontaneously yet not consciously". In another words, automatic mental procedures in their L1 were just partly automatic in their L2 and, therefore; still needed conscious control. The conclusion of this study was that the use of strategies by listeners are not always systematic but may begin as predetermined stages and gradually turn into spontaneous tactics and automatic activities. Along with studies distinguishing successful from less successful listeners, Vandergrift (1997) found that intermediate listeners applied twice as many metacognitive strategies as beginner listeners. While beginner listeners usually applied lower level cognitive strategies like repetition, transfer and translation, the intermediate listeners used more of the metacognitive strategies. 
Goh (2000) conducted a research and used students' self-reports through diaries, small group interviews and retrospective verbalizations. The results revealed that stimulus questions have a key role in inspiring the students to use helpful strategies and successful students are aware of challenges in listening (Zhang \& Goh, 2006). Vandergrift (2002) also investigated some listening processes like evaluating and predicting among beginning French students during listening tasks and introspective measures. The students were given questionnaires to complete which were specifically designed to enhance the quality of their listening task completion. The stimulus questions could actually make students aware of the underlying listening process and assist them to make use of their metacognitive recourses.

Vandergrift (2003) in his study on seventh-grade Canadian French students ranging from more to less skilled listeners, used think aloud protocols while they listened to French texts in order to compare their listening comprehension strategies. It was found that the more skilled listeners used more metacognitive strategies like monitoring and the less skilled listeners used more of translation. Chamot (2005) also reiterates that descriptive studies have supported this view that skilful language learners are adroit at applying appropriate strategies working on various tasks, whereas less skilled language learners apparently do not have the metacognitive insight about task requirements to choose relevant strategies. The results of data analysis revealed that students' introspection contributed to improve their performance and metacognitive knowledge on L2 listening tasks. The findings of some other studies have also indicated that explicit strategy instruction can obviously improve metacognitive awareness (Liu \& Goh 2006; Vandergrift, 2004).

Vandergrift, Goh, Mareschal and Tafaghodtari (2006) designed a 21-item Metacognitive Awareness Listening Questioner (MALQ). This instrument measures five different features related to metacognitive awareness and self-regulation of L2 listening including planning-evaluation, problem solving, mental translation, directed attention and person knowledge. This Likert scale questioner was initially conducted on a large international sample of 966 Iranian and French students in Canada. It also has been used in several studies by students from different cultural backgrounds including Iranians.

A combination of recent studies like Graham (2006), Cross (2011), Goh (2000, 2002), Vandergrift (2003), Vandergrift and Goh (2012), Goh and Taib (2006) and Vandergrift and Tafaghodtari (2010) have demonstrated that strategy instruction can increase metacognitive knowledge and students of various age can benefit from such metacognitive instruction.

\section{Role of Self-Efficacy in Listening Comprehension}

Bandura (1997:3) defines self-efficacy as "beliefs in one's capabilities to organize and execute the courses of action required to produce given attainments". He asserts that the perception and beliefs of learners about themselves can predict their performance better than their real capabilities. There is a mutual reciprocity between individuals' selfefficacy beliefs and how sedulous and determined they will be in pursuing their goals (Graham, 2011). It implies that in educational system, regardless of more or less ability 
of the students, the ones with high level of self-efficacy can perform better and gain higher scores than those with low level of self-efficacy. Therefore, self-efficacy perceptions can contribute to the capabilities of individuals in a way that students who believe they are capable to attain their desired goals can actually put more effort into their activities and finally succeed due to this sense of self-efficiency. Pajares (2000) also asserts that beliefs of individuals about their accomplishment and subsequent attainment strongly affect the ways in which they behave. Self-efficacy which is one of the main bases of social cognitive theory acts as a motivational variable in education and has turned out to be an indispensable element of human functions such as motivation, academic performance and learning (Pajares \& Urdan, 2006).

Learners are endowed with five capabilities to be assisted in their performance (Bandura, 1986). These capabilities include symbolizing, forethought, self-regulatory, vicarious and self-reflective skills. Self-reflection seems to be of considerable importance in assigning human behaviour because it helps people to explain, evaluate and self-assess their thoughts, psycho, motivation and performance. Bandura (1986) recognizes self-efficacy which is itself a main predictor of achievement as the most significant determiner of self-reflection.

There are four basic sources that have an impact on developing self-efficacy beliefs: mastery experience, vicarious experience, social (verbal) persuasion and physiological/affective status (Bandura, 1997). Bandura (1997) proposed that mastery experience is the most effective source. He argued that the individuals' achievement and mastery at tasks can increase their sense of self-efficiency. Therefore, mastery experience is recognized as an important arbiter of self-efficacy (Pajares, 1996). Vicarious experience as the second source of self-efficacy can improve efficacy evaluation through modelling highly self-efficacious models (Bandura, 1997). Observing the performance of peers and their achievements can stimulate insistency and sedulous effort on the part of observers (Pajares, 1997). Social (verbal) persuasion which is the third channel of intriguing self-efficacy (Bandura, 1997) is in fact verbal judgments about one's capabilities. At the time of encountering challenges and problems, this source of self-efficacy can help individuals to be optimist about their abilities in accomplishing tasks so that they would less likely lose confidence or give up their efforts. The last source of self-efficacy is emotional arousal (Bandura, 1997). It refers to improving physical status, alleviating stress and proclivities towards negative emotions (Bandura, 1997).

\section{Research Aim}

As Pajares (2000) states, little research has been done to explore the interface between self-efficacy and language achievement in comparison with other areas in teaching. Listening skill is itself the most ignored skill in second language acquisition and is compared to the Cinderella skill overlooked by its elder sister speaking (Nunan, 1997). Although during recent years, some researchers like O'Malley and Chamot (1990), Goh (2002), Goh and Taib (2006), and Vandergrift and Tafaghodtari (2010) have started to highlight the value of a strategic and process-oriented approach to listening the concept of listening self-efficacy still needs to be explored in relation to MetSI for possible 
mutual effect. According to what has been reviewed in the literature, few studies have investigated the effects of strategies on self-efficacy beliefs through the use of surveys (Yilmaz, 2010; Wang \& Li, 2010; Wong, 2005; Su \& Duo, 2012; and Magogwe \& Oliver, 2007) or interventions (Graham, 2007; Chularut \& DeBacker, 2004; Chan \& Lam, 2008; Shang, 2010; Khajavi \& Ketabi, 2012; Goker, 2006; and Zheng, Michael, Young, Robert, \& Wagner, 2009). The present study aimed to fill this gap and to investigate the impact of MetSI on EFL learners' listening self-efficacy by narrowing down the focus on one main research question:

Does metacognitive strategy instruction (MetSI) improve listening self-efficacy of Iranian EFL students?

\section{METHOD}

\section{Research design}

The study design relied on survey method to collect data from the students. Survey data collection method was applied due to its efficiency and its simple administrative process. As a brief explanation of the research design, it should be noted that a quasiexperimental design was used in which a treatment group received MetSI as an innovative method of listening instruction while the control group remained on the usual strategy-free form of training.

\section{Participants}

Sixty undergraduate female learners of English literature studying at BA level accepted the invitation to participate in this study. They were junior and senior students at the University of Qom, central Iran. After homogenizing the participants' English proficiency level by a sample section of British Council IELTS, 40 learners with intermediate to upper-intermediate level of English proficiency (who scored 6 to 7 in IELTS test) were selected. Their age varied from 22 to 29 . The students had passed at least 8 terms in EFL at institutes and all had studied English literature for one or two years at the university. They were assigned to treatment and control groups randomly. The treatment group took MetSI and the research instrument through an extracurricular class at the university. While the control group remained on the usual course of listening instruction, the treatment group was rained through MetSI. In fact, the control was not left out of any instruction but received the usual training in listening which included no MetSI. In this way the MetSI was not an additional treatment but parallel to the usual training with no focus on strategies.

\section{Instruments}

British Council IELTS as the placement test: The first instrument which was applied in this study was a sample test of IELTS adapted from British Council IELTS. It consisted of four modules of listening (20 items), speaking (an interview), reading (20 items), and writing (a composition task). The questions were in formats of table completion, classification, form completion, multiple choices, composition writing and interview. 
Listening self-efficacy questionnaire: The instrument was designed by Rahimi and Abedini (2009) based on three questionnaires of Beliefs about Language Learning (Hortwiz, 1987), Persian adaptation of the General self-efficacy Scale by Nezami, Schwarzer and Jerusalem (1996) and Morgan-Links Student Efficacy Scale (MJSES) constructed by Jinks and Morgan (1999). The questionnaire (Appendix1) consisted of 10 Likert scale items ranging from strongly disagree (1), disagree (2), partially disagree (3), partially agree (4), agree (5), to strongly agree (6). The Cronbach alpha of this instrument was 0.73 as calculated by Rahimi and Abedini (2009). It was administered to measure the level of listening self-efficacy in both groups before and after MetSI.

\section{Procedures}

First of all to determine the homogeneity of the participants before MetSI, a sample test of British Council IELTS was administered to 60 volunteers who consented to take part in this study. Forty of the students who received 6 to 8 score in 4 modules of IELTS (intermediate to upper-intermediate according to the standards of IELTS test) were selected as the participants. One week before the treatment, the researcher/teacher visited the students in both groups in order to administer listening self-efficacy questionnaire as the pre-test. Before the completion of the questionnaire the participants received some instruction about the items in that and were assisted if they had any questions regarding the meaning of the items. The participants filled out the instruments in 20-30 minutes.

The researcher/teacher in the first session of the treatment explained metacognition to the students briefly and gave them an overview of the process they were assumed to undertake based on the model proposed by Vandergrift (2003). The students received strategy instruction during listening task for 2 sessions a week. Each session took about 60 minutes and involved various listening passages. The processes of strategy instruction were divided into 8 sessions as the following:

1) The first session covered Planning/Predicting stage. The teacher gave the definition of these strategies and provided the students with some examples to contextualize them in listening situations. The teacher also provided some pre-questioning forms of advance organizers along with explanations to highlight the significance of these strategies in IELTS listening tests.

2) The second session focused on subcategory of Planning/Predicting which is directed and selective attention. Here, the teacher exemplified these strategy to the students and assisted them to concentrate on what they were listening to. The teacher drew a distinction between listening and hearing and its significance of IELTS listening tests.

3) During the third session, the strategy of self-management which is another subcategory of planning/predicting was practiced. Here, the students were taught that they should adapt themselves to various conditions encountered during listening samples and reminded them that during listening test of IELTS they have time constraints and must manage all planning/predicting strategies simultaneously to know topic and text type and subsequently predict types of information and possible words they may hear. 
4) Session four was allocated to Monitoring strategy. After giving the definition of monitoring to the students, the teacher helped the students verify initial hypothesis, correct as required and note additional information understood.

5) Session five focused on Reflection and Evaluation strategy. During this session, the students after receiving the definition of Evaluation and strategy practiced three subcategories of Evaluation which are performance evaluation, strategy evaluation and problem identification. Through this stage they became familiar with the second verification stage to verify points of disagreement and make corrections. The participants engaged in class discussions to understand how their classmates arrived at the meaning of certain words or parts of the text that they failed to recognize. Then they jotted down their peers' strategies and tactics to use in the following sessions.

6) During session six to eight the combination of all strategies were implemented according to proposed stages by Vandergrift (2003).

This lesson plan was designed by the researcher/teacher based on Vandergrift's (2003) cycle of listening instruction stages and related metacognitive strategies (See Appendix2). Finally, the teacher/researcher visited the students in both groups for the last session to administer the same listening self-efficacy questionnaire as the post-test. The students in the control group received listening tasks during the research period with no MetSI. Like the experimental group, they were given listening self-efficacy questionnaire as the post-test after 8 sessions.

\section{FINDINGS}

Before conducting the study a sample test of British Council IELTS was applied to all the population and those whose English proficiency level was measured to be intermediate to upper intermediate were selected as homogenized participants. The research question which was investigated in this study was whether MetSI improved listening self-efficacy among Iranian EFL students. In order to address this research question, descriptive and inferential statistics (independent t-test) were used to compare the level of listening self-efficacy between control and treatment groups before and after MetSI. The results of the analyses of pre-test data on EFL listening self-efficacy for control and treatment groups are summarized in Table 1 below.

Table1: Independent samples t-test for equality of mean scores in listening self-efficacy (pre-test)

\begin{tabular}{llllll}
\hline Pre-test & $N$ & Mean & $S D$ & t-Value & Significant, $P$ \\
\hline Treatment group & 20 & 62.14 & 3.381 & -.921 & .328 \\
\hline Control group & 20 & 61.62 & 3.802 & & \\
\hline
\end{tabular}

As mean scores for initial listening self-efficacy illustrated in Table 1 reveal, both control and treatment groups were rather homogeneous before MetSI regarding their listening self-efficacy and there were no statistically significant differences between the groups ( $\mathrm{t}=-.92, \mathrm{p} \geq 00.05$ ). Independent $\mathrm{t}$-test results (Table 1$)$ indicate no differences between treatment and control groups at the outset of the study in terms of listening selfefficacy. 
Having confirmed that treatment and control groups had equal listening self-efficacy before MetSI, the researchers decided to compare possible gains in listening selfefficacy after the treatment. Table 2, summarizes inferential statistics comparing the control and experimental groups in their post-test self-efficacy means.

Table2: Independent samples t-test for mean scores in listening self-efficacy (post-test)

\begin{tabular}{llllll}
\hline Post-test & $N$ & Mean & SD & t-Value & Significant, $P$ \\
\hline Treatment group & 20 & 69.24 & 3.38 & -3.341 & .012 \\
\hline Control group & 20 & 62.70 & 2.90 & -3.9 & \\
\hline
\end{tabular}

As results in Table 2 indicate, there is a statistically significant difference in the listening self-efficacy mean scores between treatment and control groups at post-test. Independent t-test results show that a significant difference has emerged between treatment and control groups by the end of the metacognitive strategy instruction period $(t=-3.34$, $\mathrm{p} \leq 0.05)$. The hypothesis of the equality of means of post-treatment listening selfefficacy is rejected implying that the treatment group significantly outperformed the control group in gaining self-efficacy as a result of listening instruction. According to this analysis, applying MetSI significantly improves listening self-efficacy among Iranian EFL students.

\section{DISCUSSION}

The results of the present study confirm the effectiveness of teaching listening through MetSI. Although learning strategies by themselves can't fully prepare EFL students for the experience of total success in comprehending audio texts, they seem to assist listener's sense of what is said to the extent of decoding critical words, phrases or the gist of the message. This can boost confidence and self-efficacy needed especially during early stages of the listening course. Regarding the present study, it is discussed that during verification stages in the model proposed by Vandergrift (2003), students get the chance to discuss and rationalize their listening problems and actively take control of their instruction process. In another words, by MetSI instructors strengthen a sense of instrumentality among listeners as they activate the awareness that there is a link between strategy use and how successfully a listening text is comprehended. In order to let MetSI cultivate instrumentality, it is essential to design models which help learners see strategy application as way of self-regulation in the process of comprehension. The lesson plan proposed in this study seems capable of bringing instrumentality and selfefficacy among students as it engages the learners in the process of listening. Therefore, metacognitive stages of prediction, monitoring, problem solving, and evaluation can move the listening class away from a model in which the teacher plays the audio tracks and asks learners comprehension questions without paying attention to their sense of reflection on the process of listening.

Based on the results, one can argue that the proposed model of MetSI does boost selfefficacy in listening comprehension classes for undergraduate learners of English. As other researchers have also noted, it is time-consuming compared with the traditional methods used in listening classes but given the basic role of self-efficacy to accelerate learning it seems the extra time would be worth-spent (Graham, 2011). 
The results gained in this study confirmed that MetSI significantly developed listening self-efficacy among EFL learners. Although no research was located that had directly investigated the impact of MetSI on listening self-efficacy, the findings of this study strengthen previous research results reported by researchers such as Graham (2007); Chularut and DeBacker (2004); Chan and Lam (2008); Shang (2010); Khajavi and Ketabi (2012); Goker (2006) and Zheng et al. (2009) who had explored the effect of general strategy training on language learners' self-efficacy beliefs.

Since the major groups of metacognitive strategies including prediction, monitoring, problem solving, and evaluation help students learn how to bring their metacognitive knowledge and self-regulation in listening into consciousness they can raise the perception and awareness of listeners about themselves during the process of listening. According to the results of the study by Vandergrift (2002) the students confirmed the power of prediction on successful listening and they also recognized the contributions of negotiating with partners through monitoring. Therefore, metacognitive approach in listening can have a confidence building role in increasing self-efficacy among listeners. All of these outcomes can foster four basic sources of self-efficacy beliefs including mastery experience, vicarious experience, social persuasion and physiological/affective status among listeners.

\section{Implications of the study}

The results of this investigation indicate the necessity for the language teachers, especially in Iran, to pay more attention to a strategic approach to the listening task in classrooms and replace product-oriented with process-oriented instruction to improve the level of listening self-efficacy among the learners. The results of this study also have the implication for listening teachers to implement metacognitive strategies which create opportunities to see successful performance of peers in accomplishing listening tasks. This can boost positive beliefs among learners.

\section{Limitation and Recommended Future Studies}

This study focused on EFL university students and investigated the impact of activating metacognitive strategies on their listening performance. Due to some limitations in this research including single gender, relatively small sample size and English language proficiency, generalizing the results should be done cautiously. Since it was a classroom-based study at a segregated university, it was not possible to find a large group of EFL students of both genders and at various levels of English proficiency to take part in this research. Therefore, because of opportunistic reasons all the participants had single gender (female). In fact, there's a dire need to do more quantitative and qualitative studies with larger sample size from both genders and at various levels of English proficiency including lower or more advanced levels to come to a consensus regarding the effect of metacognitive strategies on listening self-efficacy among Iranian EFL students. It is hoped that future researches will open up new horizons into this neglected skill in EFL teaching in Iran.

Future research should also be designed to include more comprehensive qualitative methods to gain deeper knowledge of the perception of learners regarding the impact of 
metacognitive strategies on the listening performance by focusing on qualitative analysis of interview results and retrospective measures. Therefore, applying think aloud protocols to observe students' internal cognitive processing seems useful in this area.

As for suggestions regarding future research it seems that conducting more qualitative studies to explore the perception of the learners of the impact of MetSI on listening selfefficacy is necessary to unfold the underlying links between self-efficacy and metacognition and listening. Interviewing the students or using introspective measures can deeply investigate underlying processes which lead to developing listening selfefficacy. Conducting more longitudinal studies also seem beneficial in this area as mostly researchers have just applied interventions in short- term periods

\section{CONCLUSION}

The results gained in this study confirmed that MetSI significantly developed listening self-efficacy among EFL learners. In fact, because MetSI develops five factors of metacognitive knowledge (planning and evaluation, problem solving, directed attention, mental translation and person knowledge), it can also nurture the self-beliefs and emotional support among listeners and thereby promote authentic mastery and successful experiences among them. Learners of English as a foreign language are supposed to be taught to show agency in their learning and to control their acquisition of all skills including listening. As Pajarus (2000) recommended, teaching practices at school should be evaluated according to their contributions to foster self-efficacy of students. Due to the contributions of self-efficacy to all language skills including listening comprehension, it is considered of high importance for instructors to equip their students with some strategies to enhance their self-efficacy. In fact, such strategies can bring the experiences of success and performance accomplishment and thereby lead to higher self-efficacy among learners.

\section{REFERENCES}

Bandura, A. (1986). Social foundations of thought and action: A social cognitive theory. Englewood Cliffs, NJ: Prentice Hall.

Bandura, A. (1997). Self-efficacy: The exercise of control. New York: W. H. Freeman and Company.

Bone, D. (1994).The business of listening: A practical guide to effective listening. Los Altos California: Crisp Publications.

Chamot, A. U. (1993). Student responses to learning strategy instruction in the foreign language classroom. Foreign Language Annals, 26, 308-321.

Chamot, A. (2005). Language learning strategy instruction: Current issues and research. Annual Review of Applied Linguistics, 25, 112-130.

Chan, J. C. Y., \& Lam, S. F. (2008). Effects of different evaluative feedback on students' self-efficacy in Learning. InstrSci, 38, 37-58.

Chularut, P., \& DeBacker, T. K. (2004). The influence of concept mapping on achievement, self-regulation, self-efficacy and in students of English as a second language. Contemporary Educational Psychology, 29, 248-263. 
Cohen, A. D. (1998). Strategies for learning and using a second language. Longman, Essex, UK.

Cross, J. (2011). Metacognitive instruction for helping less skilled students. ELT Journal, 65(4), 408-416.

Goh, C. (1997). Metacognitive awareness and second language students. ELT Journal, 51, 361-369.

Goh, C. (1998). How ESL students with different listening abilities use comprehension strategies and tactics. Language Teaching Research, 2(2), 124-47.

Goh, C. (2000) A cognitive perspective on language students' listening comprehension problems. System, 28(1), 55-75.

Goh, C. (2002). Students' self-reports on comprehension and learning strategies for listening. Asian Journal of English Language Teaching, 12, 46-68.

Goh, C. (2008). Metacognitive instruction for second language listening development: Theory, practice and research implications. RELC Journal, 39(2), 188- 213. http://dx.doi.org/10.1177/0033688208092184

Goh, C., \& Taib, Y. (2006). Metacognitive instruction in listening for young students. ELT Journal, 60, 222-232.

Goker S. D. (2006). Impact of peer coaching on self-efficacy and instructional skills in TEFL teacher education. System, 34, 239-254.

Graham, S. (2006). Listening comprehension: The students' perspective. System: An International Journal of Educational Technology and Applied Linguistics, 34, 165-182.

Graham, S. (2007). Learner strategies and self-efficacy: Making the connection Language Learning Journal, 35, 81-93.

Graham, S. (2011). Self-efficacy and academic listening. Journal of English for Academic Purposes, 10(2). 113-117. http://dx.doi.org/10.1016/j.jeap.2011.04.001.

Hassan, A.S. (2000). Students' perception of listening comprehension problems. Language, Culture and Curriculum. 13(2), 137-153.

Horwitz, E. K. (1987). Surveying student beliefs about language learning. In Wenden, A. L., and J. Rubin (Eds.), Student Strategies in Language Learning (pp. 119-129). Prentice-Hall, Englewood Clips, NJ, pp.

Jinks, J.L., \& Morgan, V.L., (1999). Children's perceived academic self-efficacy: an inventory. $\quad$ Retrieved 13/9/2004, from http://www.coe.ilstu.edu/scienceed/jinks/efficacypub97.htm.

Khajavi, Y., \& Ketabi, S. (2012). Influencing EFL learners' reading comprehension and self-efficacy beliefs: The effect of concept mapping strategy. Porta Linguarum, 17, 927.

Liu, X. L., \& Goh, C. (2006). Improving second language listening: Awareness and involvement. In T. S. C. Fareell (ed.), Language teacher research in Asia (pp.91-106). Alexandria, VA: TESOL.

Lynch, T. (1998). Theoretical perspectives on listening. Annual Review of Applied Linguistics, 18, 3-19. http://dx.doi.org/10.1017/S0267190500003457 
Macaro, E., Graham, S., \& Vanderplank, R. (2007). A review of listening strategies: Focus on sources of knowledge and on success. In E. Macaro \& A. Cohen (Eds.), Language learner strategies: 30 years of research and practice (pp. 165-185). Oxford, England.

Magogwe, J. M., \& Oliver, R. (2007). The relationship between language learning strategies, proficiency, age and self-efficacy beliefs: A study of language learners in Botswana. System, 35, 338-352.

Mareschal, C. (2007). Students' perception of a self-regulatory approach to second language listening comprehension development (Doctoral dissertation, University of Ottawa, Canada).

Mendelsohn, D. J. (1994). Learning to listen. San Diego: Dominie Press.

Mendelsohn, D. (1995). Applying learning strategies in the second/foreign language listening comprehension lesson. In D. Mendelsohn \& J. Rubin (Eds), A guide for the teaching of second language listening. San Diego, CA: Dominic Press.

Nezami, E., Schwarzer, R., \& Jerusalem, M. (1996). Persian Adaptation (Farsi) of the General Self-Efficacy Scale. Retrieved 29th July, 2007 from userpage.fuberlin. de/ health/persean.htm.

Nunan D. (1997). Listening in language learning. The Language Teacher. The Japan Association of Language Learning, 21(9), 47-51.

O’Malley, J. M., \& Chamot, A. U. (1990). Learning Strategies in Second Language Acquisition. Cambridge University Press, Cambridge.

O’Malley, J. M., Chamot, A. U., \& Kupper, L. (1989). Listening comprehension strategies in second language acquisition. Applied Linguistics, 10, 418-437.

Oxford, R. L. (1990). Language learning strategies: What every teacher should know. Boston, MA: Heinle \& Heinle, Boston.

Oxford, R.L., Lavine, R.Z., \& Crookall, D. (1989). Language learning strategies, the communicative approach, and their classroom implication. Foreign Language Annals, 22, 29-39.

Pajares, F. (1996). Self-efficacy beliefs in academic settings. Review of Educational Research, 66(4), 543-578.

Pajares, F. (1997). Current directions in self-efficacy research. In M. Maehr, \& P. R. Pintrich (Eds.), Advances in motivation and achievement (Vol. 10, pp. 1-49). Greenwich, CT: JAI.

Pajares, F. (2000). Self-efficacy beliefs and current directions in self-efficacy research. Retrieved June, 2008 from http://www.emory.edu/EDUCATION/mfp/effpage.html.

Pajares, F., \& Urdan, T. (2006). Foreword. In F. Pajares, \& T. Urdan (Eds.), Selfefficacy beliefs of adolescents (pp. ix-xii). Greenwich, CT: Information Age Publishing. Rahimi, A., \& Abedini, A. (2009). The Interface between EFL learners' self-efficacy concerning listening comprehension and listening proficiency. Novitas-ROYAL, 3(1), $14-28$. 
Roberts, J. J., \& Gous, I. G. (2014). ODEL-Open and Distance Education and listening: The need for metacognitive listening strategies. Journal of Educational and Social Research, 4(3), 63-70.

Rubin, J. (1994). A review of second language listening comprehension research. The Modern Language Journal, 78(2), 199-221. http://dx.doi.org/10.2307/329010.

Shang, H. F. (2010). Reading Strategy Use, Self-Efficacy and EFL Reading Comprehension. The Asian EFL Journal Quarterly, 12(2), 18-42.

Su, M. H., \& Duo, P. C. (2012). EFL learners' language learning strategy use and perceived self- efficacy. European Journal of Social Sciences, 27(3), 335-345.

Vandergrift, L. (1997). The comprehension strategies of second language (French) students: A descriptive study. Foreign Language Annuals. 30(3), 387-409.

Vandergrift, L. (2002). It was nice to see that our predictions were right: Developing metacognition in L2 listening comprehension. The Canadian Modern Language Review, 58, 555-575.

Vandergrift, L. (2003). Orchestrating strategy use: Toward a model of the skilled second language listener student. Language Learning. 53(3), 463-496.

Vandergrift, L. (2004). Listening to learn or learning to listen? Annual Review of Applied linguistics (2004), 24, 3-25.

Vandergrift, L., \& Goh, C. (2012). Teaching and learning second language listening: Metacognition in action. Taylor \& Frances Group. New York. Reuledge.

Vandergrift, L., \& Tafaghodtar, H. M. (2010). Teaching L2 students how to listen does make a difference: An empirical study. Language Learning, 60(2), 470-497.

Vandergrift, L., Goh, C. C. M., Mareschal, C. J., \& Tafaghodtari, M. H. (2006). The metacognitive awareness listening questionnaire: Development and validation. Language Learning, 56 (3), 431-462.

Wang, C., \& Li, Y. (2010). An Empirical Study of Reading Self-Efficacy and the Use of Reading Strategies in the Chinese EFL Context. The Asian EFL Journal Quarterly, 12(2), 144-162.

Wong. M. S. L. (2005). Language learning strategies and language self-efficacy: Investigating the Relationship in Malaysia. Regional Language Centre Journal, 36(3), 245-269.

Yilmaz, C. (2010). The relationship between language learning strategies, gender, proficiency and self-efficacy beliefs: A study of ELT learners in Turkey. Procedia Social and Behavioural, 2, 682-687.

Zhang, D., \& Goh, C. (2006). Strategy knowledge and perceived strategy use: Singaporean student' awareness of listening and speaking. Language Awareness, 15, 199-219.

Zhang, D., Michael F., Young, M., Robert, B., \& Wagner, M. (2009). Attitude and selfefficacy change: English language learning in virtual worlds. CALICO Journal, 27(1), 205-231. 


\section{Turkish Abstract \\ İranlı İngilizce Öğrenen Lisans Öğrencilerinin Dinleme Becerisi Öz-Yeterliklerini Geliștirmede Bilişötesi Strateji Öğretimi}

Bilişötesi strateji öğretimi İngilizce'nin yabancı dil ya da ikinci dil olarak farklı yönlerinin öğretiminde güçlü bir etkiye sahip olduğu gösterilmiştir. Bu çalışma yabacı dil olarak İngilizce'yi öğrenenlerde dinleme öz-yeterliğinin gelişmesinde bilişötesi stratejilerin etkisini incelemeyi amaçlamaktadır. İran'da bir devlet üniversitesinde İngiliz edebiyatı lisans bölümünde okuyan 60 öğrenci bu çalışmada yer almışlardır. British Council IELTS testi kullanılarak katılımcıların İngilizce yeterlik düzeylerinde homojenlik sağlanarak orta seviye grubundan 40 öğrenci seçilmiştir. Ön test ve son test aşamalarında öğrencilerin dinleme öz-yeterlik düzeylerini ölçmek için Rahimi ve Abedini (2009) 'dan alınan dinleme öz yeterlik ölçeği kullanılmıştır. Katılımeılar deney grubu $(\mathrm{n}=20)$, ve kontrol grubuna $(\mathrm{n}=20)$ rassal olarak atanmışlardır. Kontrol grubuna herhangi bir müdahalede bulunulmazken, deney grubu Vandergrift (2003) tarafindan önerilen bir modele dayanarak 8 oturumda 8 saatlik bir bilişötesi strateji öğretimi almışlardır.

Anahtar Kelimeler: Bilişötesi strateji öğretimi, Dinleme öz-yeterliği, Dinlediğini anlama, Dil öğretimi, Yabanc1 Dil

\section{French Abstract}

Metacognitive Instruction de Stratégie comme un moyen pour Améliorer Auto-efficacité Écoutante parmi les Apprenants en Licence Iraniens d'anglais

Metacognitive l'instruction de stratégie (MetSI) a montré pour avoir un impact fort sur les aspects divers d'anglais comme une instruction de seconde/langue étrangère. L'étude présente a eu pour but d'examiner l'effet de MetSI sur l'amélioration d'auto-efficacité écoutante parmi l'Anglais langue étrangère (EFL) des apprenants. Un groupe de soixante apprenants en licence féminins de littérature anglaise à une université gérée par l'État en Iran a consenti à participer à cette étude. Après l'homogénéisation du niveau de compétence anglais des participants utilisant une section type du British Council IELTS le test, 40 apprenants ont été choisis dont la compétence anglaise est tombée dans l'intermédiaire au niveau supérieur-intermédiaire. Un questionnaire d'autoefficacité écoutant (emprunté à Rahimi et Abedini, 2009) a été utilisé pour mesurer le niveau des participants d'auto-efficacité écoutante dans les phases pré et post-de-test de l'étude. Les participants ont été aléatoirement assignés au traitement $(n=20)$ et le contrôle $(n=20)$ des groupes. Le groupe de traitement a reçu 8 heures de MetSI pendant huit sessions basées sur le modèle proposé par Vandergrift (2003) tandis que le groupe témoin n'a pas reçu de MetSI explicite. Le groupe témoin a reçu la formation habituelle dans l'écoute au lieu de cela.

Mots-clés: Metacognitive Instruction de Stratégie (MetSI), Écoutant Auto-efficacité, Écoutant Compréhension, Instruction de Langue, Langue Etrangère 


\begin{abstract}
Arabic Abstract
العنوان: إستراتيجية تعليم ما وراء المعرفة كوسيلة لتحسين إسنماع الكفاءة الذاتية بين طلاب اللغة الإنجليزية الإبرانيين في المرحلة الجامعيةً

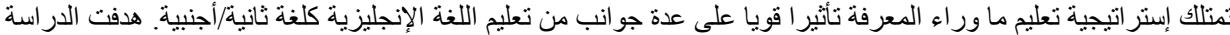

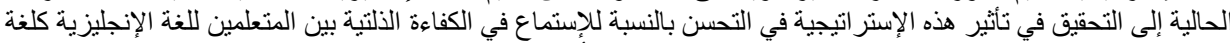

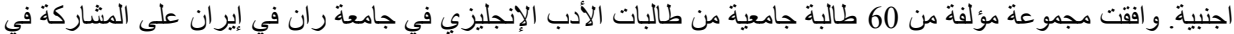

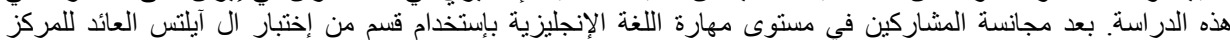

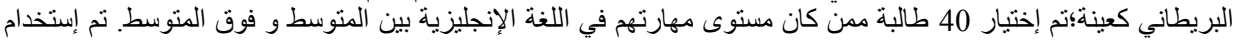

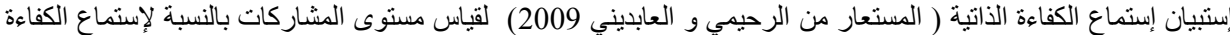

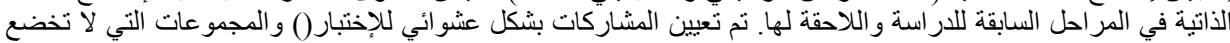

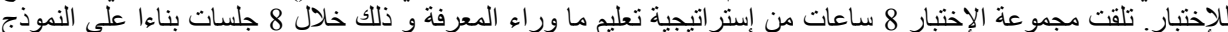

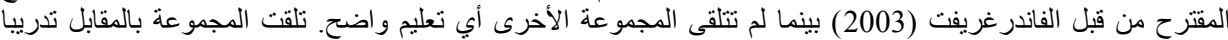
إعتياديا على الإستماع.

كلمات مهمة: استر اتيجية تعليم ما ور اء المعرفة, استماع الكفاءة الذاتية, الإستماع و الفهر,تعليم اللغة, اللغة الأجنيبة.
\end{abstract}

